Available online at: https://proceeding.researchsynergypress.com/index.php/rsfconferenceseries1

RSF Conference Series: Business, Management and Social Sciences

e-ISSN 2807-5803/ p-ISSN 2807-6699

Volume 1Number 4 (2021): 124-133

\title{
Implementation of ADDIE Model in Improving the Ability of Lecturers to Write Scientific Articles in Accredited Journals
}

\author{
Arif Wibawa1, Panji Dwi Ashrianto², Sigit Tri Pambudi ${ }^{3}$ \\ ${ }^{123}$ Department of Communication Sciences UPN “Veteran” Yogyakarta
}

\begin{abstract}
The writing ability of the lecturers of the Communication Studies Study Program still needs to be improved considering that the number of scientific articles written by the UPN "Veteran" Yogyakarta lecturers in general and the lecturers of the Communication Studies Study Program, in particular, is still tiny, so it is deemed necessary to carry out specific assessments of the lecturers so that the number of scientific articles written in Accredited journals is increasing. Improving the writing ability of lecturers in accredited journals is carried out through training with the Addie model. This study aims to find out how the Addie model is used by the Communication Studies Study Program to improve the pedagogic competence of lecturers in terms of the ability to write accredited journals. Using the Research and Development (RnD) approach through the stages of the ADDIE model, this study involved 30 lecturers of the Department of Communication Sciences UPN "Veteran" Yogyakarta as participants. The results of this study are the training model. The developed training model is quite effective in increasing the ability of participants to write and produce scientific papers of international standard. This can be seen from the changes in the contents of the manuscripts submitted before and after the training and the assessment carried out by the supervisors, which showed significant progress in the quality of the participants' writings. The training activities also increased the perception of lecturers in the Department of Communication Sciences UPN Veteran Yogyakarta regarding their ability to write scientific papers for international publications.
\end{abstract}

Keywords: Research and Development, ADDIE Model, Article Writing

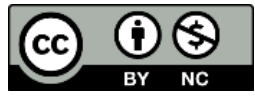

This is an open access article under the CC-BY-NC license

\section{INTRODUCTION}

The main task of a lecturer in the research is embodied in the tri dharma of higher education. In addition to teaching, lecturers are required to conduct research and community service. However, often these two things are not carried out optimally due to various things. Whereas through research, many of the resulting impacts can be beneficial for the development of science itself, society, and universities. More research produced by lecturers at a university can encourage the improvement of the reputation rating for the institution.

One of the obstacles that lecturers often face is the ability to write scientific articles. This ability is essential so that the results of scientific research conducted by lecturers can be disseminated appropriately. The scientific findings produced in the research carried out can be used by other parties for reference for further research. Thus, the development of science can occur with the dissemination of research results.

Awareness of the importance of writing scientific articles for lecturers is increasingly visible through various government policies that have been prepared. Law No. 12 of 2012 states that it is obligatory for lecturers who hold Head Lecturer and Professor positions to write scientific articles in indexed and reputable national and international scientific journals.

Corresponding author:

wibawa.arif@yahoo.com; panjidwiashrianto@upnyk.ac.id; mrsgt_upnyk@yahoo.com

DOI: $10.31098 /$ bmss.v1i4.353

Research Synergy Foundation 
The ability to write articles is a determining ability in academic positions. The urge to improve students' ability to write scientific articles has become increasingly intense lately. This is due to the low contribution of researchers in Indonesia in scientific publications at the world level. Indonesia is the number two country after Malaysia in scientific publications. This low contribution means that Indonesia has not yet received a proper place in scientific publications.

The Indonesian government has a solid commitment to improving the quality and quantity of lecturers' publications. In line with the increasing funding support from the government, universities and universities must manage their research agenda more professionally. Responding to such a policy direction, the government expects all productive lecturers to innovate to produce quality research results. The government also requires that any research produced to be published in accredited national journals or reputable international scientific journals.

UPN "Veteran" Yogyakarta is one educational institution that must actively improve lecturers' writing skills in accredited scientific journals. It is also stated in the Main Performance Index (KPI), determined by the Chancellor of UPN "Veteran" Yogyakarta.

Efforts to improve the ability of lecturers to write scientific articles in accredited journals will be carried out using the ADDIE model. This model uses a systems approach. The essence of the systems approach is to divide the training planning process into several steps. Organize the steps into logical sequences, then use the output of each step as input to the next step. Expected increase writing skills in accredited scientific journals can be increased with this Addie model training.

From this background, this research aims to find out how the Addie model is used by the Communication Studies Study Program to improve the pedagogic competence of lecturers in terms of the ability to write accredited journals? This research is expected to foster writing scientific articles in accredited journals both nationally and internationally. The academic atmosphere in the form of a passion for writing scientific articles is expected to develop well. This enthusiasm will support the achievement of the Research and Development Institute Main Performance Index (LPPM), which the chancellor has determined. It will also affect the achievement of the university's KPI in terms of the number of scientific papers published in international journals.

\section{LITERATURE REVIEW}

\section{ADDIE Model and Persuasive Communication Concept}

This research is a research development model of mentoring for lecturers in writing scientific articles in accredited journals. One of the models that can be used in development research is the Analysis, Design, Development, Implementation, Evaluation (ADDIE Model) model. The ADDIE model is one of the most commonly used models in instructional design (Aldoobie, 2015). This model has the principle of an effective, efficient, and interactive system approach because each phase will produce an evaluation that can be used to reach the next phase.

Although some have criticized the ADDIE model for being too systematic, linear, inflexible, too restrictive, and even too time-consuming to implement, however, according to Vejvodova's findings, this model is very systematic, providing much flexibility, as it may be necessary to develop training (Vejvodová, 2009). The most critical phase is the analysis phase. Some designers find this stage time-consuming. However, this saves money and time in the long run because when the appropriate training tools are applied in the right situations, the result is adequate training for all parties.

Although many instructional design models contain five generic phases (Azimi \& Rastegarpour, 2015; Moradmand et al., 2014; Taylor, 2004), the stages of learning development through the ADDIE model are analysis, design, development, implementation, and evaluation (FAO, 2021; Moradmand et al., 2014). It should be noted that the ADDIE model is a continuous process, with each phase interacting with 
each other in turn (Allen, 2006). The analysis stage is a process of "defining" what learners want to learn (FAO, 2021; Moradmand et al., 2014). In this first process, a needs analysis is needed regarding what things need to be studied, identifying problems or needs, and conducting assignment analysis. In this process, the outputs produced are in the form of characteristics or profiles of prospective learning participants, identification of gaps, identification of needs, and detailed task analysis according to learning needs.

Second stage design. At this stage, the draft or a work plan was made to formulate learning objectives, in this case, the purpose of training assistance. After that, it is also necessary to determine the appropriate learning or training strategy to achieve the goal in this process. In this second stage, there are many media and varied methods of mentoring or training to be adapted to the learning objectives.

The third stage is development. In the process, it should be realized that the design created in the previous stage practiced a reality. If, at this stage, a module or software development needs, it needs to be developed. It is also essential to conduct a trial implementation at this stage, and the evaluation results will be used for further development of this process. The fourth stage is implementation, which is implementing the learning system after the developments are adapted to its function. For example, if learning or mentoring requires specific software, it must be installed in terms of implementation. The last stage is evaluation, which requires an evaluation of the mentoring system to see how far the success or failure of the mentoring system has been. At this stage, it may require input from experts on the mentoring design made for further development.

In the context of this research, the ADDIE model can be used to make the system more effective and help as needed. The implementation of the ADDIE model will be more meaningful when accompanied by a persuasive communication strategy. In learning theory, learning activities will always be followed by cognitive, psychomotor, and effectiveness changes, For example, changes in skills, attitudes, understanding, values, and others. To achieve this, persuasive communication is needed, especially from learning companions to study participants (in this case, scientific article writing companions to lecturers). According to Borman (1976), persuasive values used in discussions can change behavior in groups compared to mentoring that is carried out only by giving lectures and reading. Hovland mentions that persuasive communication will be more effective if done by experts (competent people) (Hovland, 2005). In addition, persuasion can be developed by messages that generate strong emotions for someone, especially if the message conveys contains recommendations to change attitudes and behavior.

The concept of persuasive communication can then be a knife to sharpen the analysis in this research. About how people who are competent in writing scientific journal articles can arouse emotions or enthusiasm to write scientific articles based on their experiences to effectively change the habits of lecturers who help write quality scientific articles.

\section{RESEARCH METHODOLOGY}

In answering the problem formulation, this research will use the Research and Development (RnD) method. The Research and Development method is research that aims to develop a model, either in the form of hardware (hardware) or in the form of software (software) (Borg \& Gall, 1989). RnD is also a research method used to produce specific products and test the effectiveness of these products (Sugiyono, 2016). Research and Development is a research method that is intentionally and systematically used to find, improve, develop, produce, and test products, models, or methods or strategies and ways that are superior, new, effective, productive, and meaningful (Putra, 2015). ). Borg and Gall (1983) explain that the term product refers to material objects, such as textbooks, learning films, and others., and procedures and processes, such as learning methods or methods for organizing learning.

In this study, by collaborating with the ADDIE model and the Research and Development method, researchers will formulate or identify needs in mentoring lecturers, determine strategies, realize strategic designs, implement mentoring systems, and conduct evaluations. 


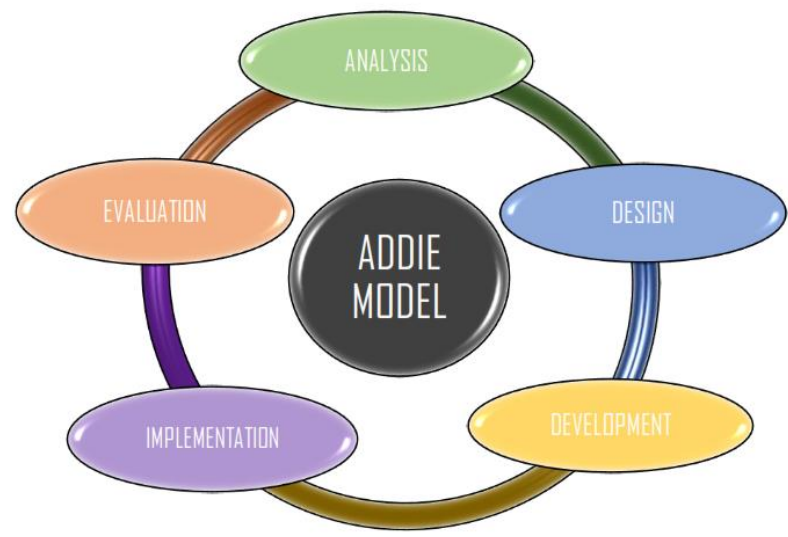

Figure 1. ADDIE model research procedure

This study involved 30 lecturers of the Department of Communication Sciences UPN "Veteran" Yogyakarta as participants. Data is collected based on facts according to the type of data used. Survey techniques, questionnaires, interviews, field observations, and manuscript collection were used to collect primary data. For secondary data, documentation review techniques are used. A combination of data collection instruments is expected to produce more comprehensive data from this model development research.

Furthermore, the research and development research data will be presented and analyzed through persuasive communication concepts and theories related to the implementation of the ADDIE model. The analytical technique used in this qualitative research will be based on the Interactive Analysis Model (Miles \& Huberman, 1992). According to this model in data collection, researchers always make data reductions and data presentations continuously until a conclusion is drawn up.

\section{FINDING AND DISCUSSION}

The first stage carried out is determining the needs analysis (need analysis) through a survey of 30 lecturers in the Department of Communication Sciences UPNVY. The result is that each lecturer publishes an average of 4 scientific articles within three years. Lecturers experience some difficulties related to writing and publishing scientific articles. First, regarding writing, most lecturers have difficulty finding literature reviews (36\%) and the correct theory (36\%). 


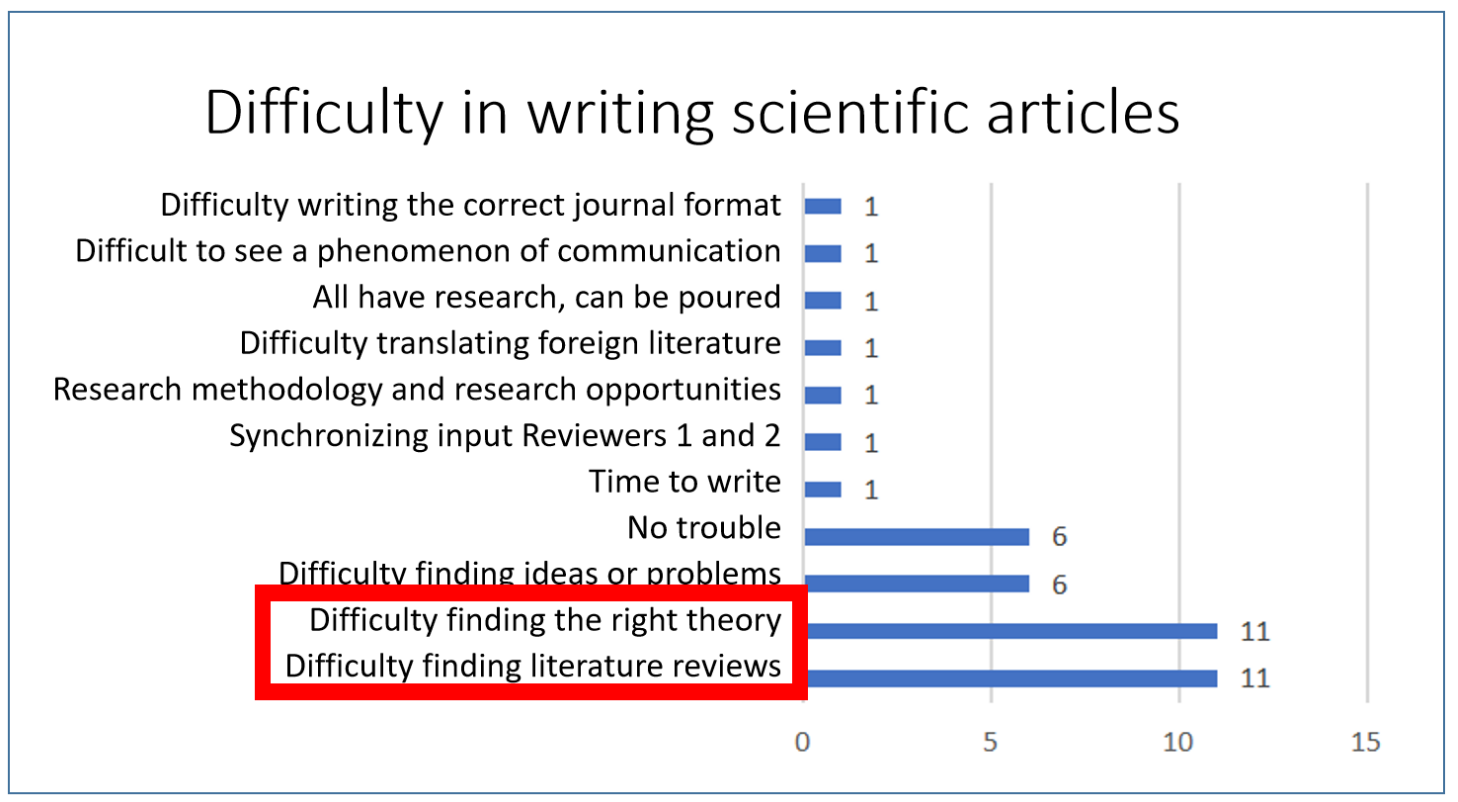

Figure 2. Types of difficulties in writing scientific articles

Second, related to publication, the most dominant difficulty felt was related to the length of time for publication (57\%) and the high cost of publication (63\%).

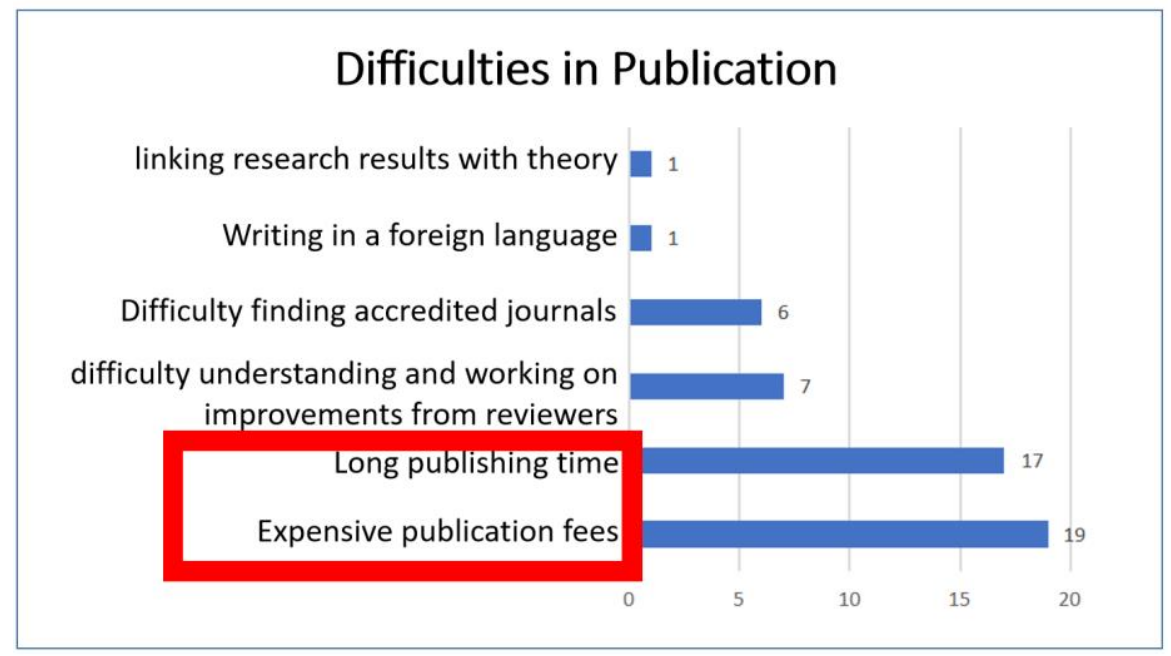

Figure 3. Difficulties in publication by lecturers

Meanwhile, UPNVY Communication Studies lecturers have sufficient mastery of 9 skills in writing and publishing scientific articles (pouring research problems, implementing theory, presenting research data, presenting novelties, how to refer and making reference lists, presenting articles and tables according to OJS format, search for and enter articles in destination journals). 
RSF Conference Series: Business, Management and Social Sciences

Volume 1Number 4 (2021): 124-133

Implementation of ADDIE Model in Improving the Ability of Lecturers to Write Scientific Articles in Accredited Journals

Arif Wibawa, Panji Dwi Ashrianto, Sigit Tri Pambudi

\begin{tabular}{|c|l|c|c|}
\hline NO & \multicolumn{1}{|c|}{ ABILITY } & $\begin{array}{c}\text { MAJORITY } \\
\text { ANSWER }\end{array}$ & $\begin{array}{c}\text { PROCENTAG } \\
\text { E }\end{array}$ \\
\hline 1. & Ability to express research problems & Master & $53 \%$ \\
\hline 2. & Apply specific theories & Master & $47 \%$ \\
\hline 3. & Presenting novelty & Master & $37 \%$ \\
\hline 4. & How to refer & Master & $47 \%$ \\
\hline 5. & How to write a list of references & Master & $53 \%$ \\
\hline 6. & $\begin{array}{l}\text { Presenting articles, tables, and images } \\
\text { according to the format provisions in } \\
\text { the journal }\end{array}$ & Master & $53 \%$ \\
\hline 7. & Search for journals of interest & Master & $53 \%$ \\
\hline 8. & Submit articles to journals & Master & $47 \%$ \\
\hline 9. & Follow the publication & Master & $32 \%$ \\
\hline
\end{tabular}

Figure 4. The ability of the lecturer before the training

Temporary for the stage design or determining the method based on the results of the needs analysis. From this stage, it is concluded that it is necessary to use two methods to improve the quality of lecturers in writing scientific journal articles, namely workshops and module making. The workshop conducted as a mentoring effort through seminars and writing clinics. The workshop material provided focuses on abilities that are still considered lacking. Meanwhile, the module is made as a complementary component to facilitate lecturers/participants in participating in the writing clinic. The module also becomes the research output that can be used for similar activities in the future.

The next stage in development or development. In the development stage, there are at least two important objectives that need to be achieved, among others, (a) Produce or revise training materials that will be used to achieve the training objectives that have been formulated, (b) Choose the best form of training that will be used to achieve the training objectives.

Some The points that need to be obtained in this stage include: (1) The form of training materials that need to be made in achieving the goals of Education and Training for lecturers, (2) The form of training that needs to be created and modified so that it can meet the objectives of Education and Training for lecturers.

The prepared training materials are in the form of modules containing the stages and research flows developed based on inputs from the speakers invited to the training. In comparison, the form of training is prepared in 2 stages, including the stage of providing material and assisting in writing articles. The stage of providing the material is carried out in 1 meeting. The mentoring stage is given in 2 meetings directly and in; the process also uses consultation in the form of an email. 


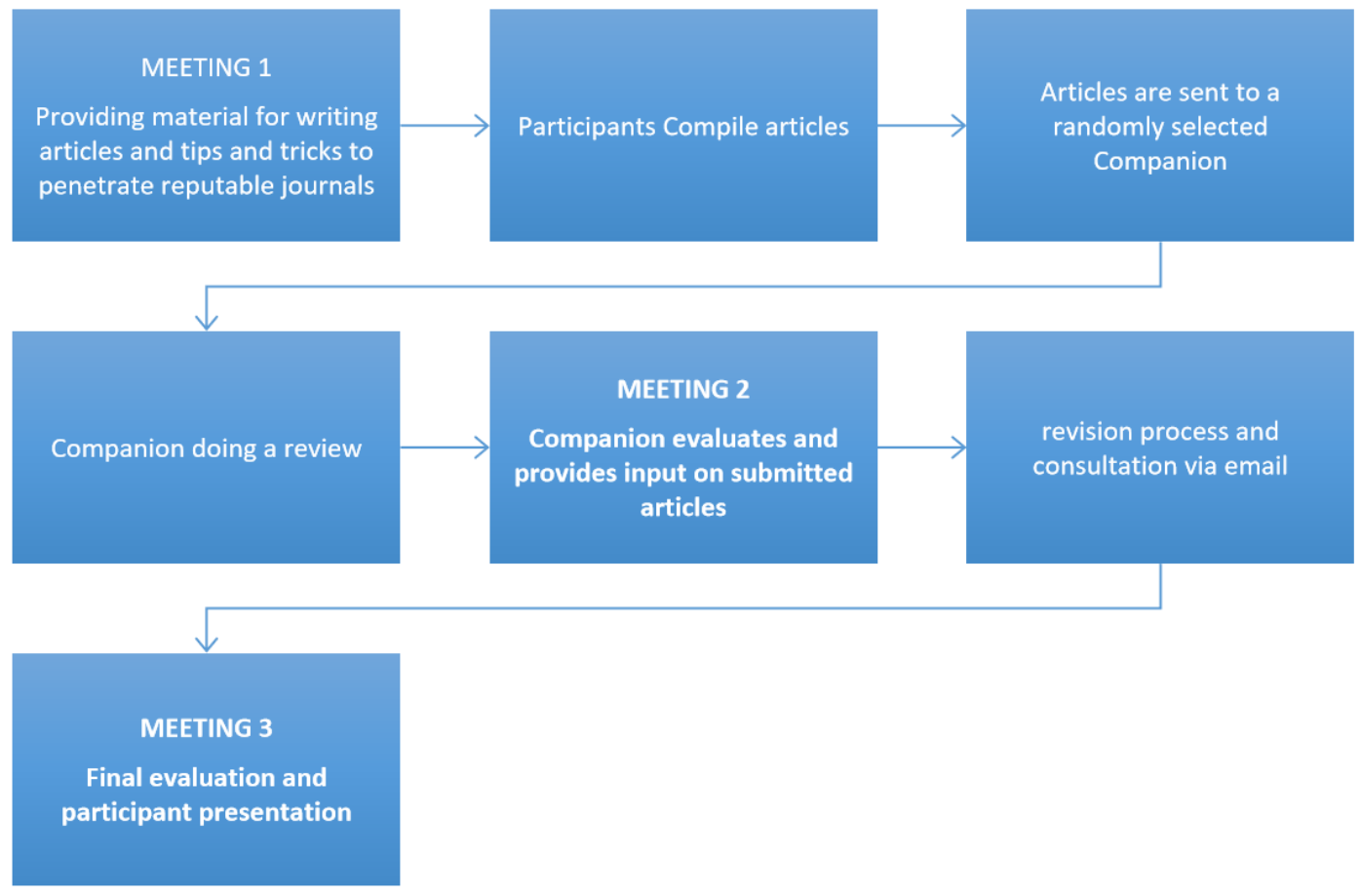

Figure 5. Training flow

The next stage is the implementation stage. After determining the scientific article training model, the researcher then tested the conceptual model designed for the trainees. The entire training is carried out online using the Zoom Meeting application. Participants attended the workshop at the first meeting for approximately 3 hours, divided into two sessions, namely a presentation session and a question and answer session.

During the meeting, the researcher conducted field observations to produce the data needed in the evaluation phase of the training development model. After the first meeting, participants were given one week to compile scientific articles, and then the articles were collected to the researchers to be submitted to the companion. Initially, there were 22 scientific articles from research and community service lecturers in the Department of Communication Studies $668.75 \%$ of whom submitted articles for training or mentoring). On the way, after going through an evaluation by a mentor at a coaching clinic activity, only 17 articles out of 22 entries met the complete requirements for journal writing. At the same time, the other five articles are not finished in writing.

There were three assistants involved, each of whom was tasked with reviewing ten articles. The articles that have been reviewed are then given to the participants at the second meeting. At the second meeting, the facilitator explained, one by one, the results of the review to the participants for further revision. At the revision stage, participants use e-mail to consult with companions. After the mentoring process is complete, the facilitator provides input or review notes on the 22 articles entered at the beginning of the mentoring. However, only 12 articles were repaired (or approximately $54.4 \%$ of the total articles that go in the beginning). This indicates that not all lecturers have a high commitment to participate in the training and mentoring process. However, the lack of commitment did not happen just because of several factors, namely busyness, lack of time to repair articles, and unfinished research. The last step in the implementation stage is that participants explain the final results of their scientific articles that have been corrected to their companions and the intended journal plan. 
The last stage of the ADDIE model is evaluation. After all the meetings were implemented for the training participants, the researcher gave the Need Analysis survey back to the trainees to see how the trainees' perceptions were after experiencing international scientific writing training for three meetings.

\begin{tabular}{|c|l|c|c|}
\hline NO & \multicolumn{1}{|c|}{ ABILITY } & $\begin{array}{c}\text { MAJORITY } \\
\text { ANSWER }\end{array}$ & $\begin{array}{c}\text { PROCENTAG } \\
\text { E }\end{array}$ \\
\hline 10. & Ability to express research problems & Master & $68 \%$ \\
\hline 11. & Apply specific theories & Master & $63 \%$ \\
\hline 12. & Presenting novelty & Master & $63 \%$ \\
\hline 13. & How to refer & Master & $42 \%$ \\
\hline 14. & How to write a list of references & Master & $68 \%$ \\
\hline 15. & $\begin{array}{l}\text { Presenting articles, tables, and images } \\
\text { according to the format provisions in } \\
\text { the journal }\end{array}$ & Master & $47 \%$ \\
\hline 16. & Search for journals of interest & Master & $58 \%$ \\
\hline 17. & Submit articles to journals & Master & $58 \%$ \\
\hline 18. & Follow the publication & Master & $47 \%$ \\
\hline
\end{tabular}

Figure 6. The abilities of the lecturers after the training

The results of the post-training survey showed that the majority of participants acknowledged that:

1. The ability of participants to describe problems clearly in articles has increased. Before the training, participants with the skill "quite mastered (53\%)", while after the training, the participants with the skill "master (68\%)" dominated.

2. The ability of participants to apply theory specifically to articles has increased. Before the training, participants with the skill "quite mastered (42\%)", while after the training, participants with the skill "mastered (63\%)" dominated the training.

3. The ability of participants to present a novelty in articles has increased. Before the training, participants with the skill "quite mastered (37\%)", while after the training, participants with the skill "mastered (63\%)" dominated the training.

4. The ability of participants to refer to sources has increased. Before the training, participants with the skill "quite mastered (47\%)", while after the training, participants with the skill "master (42\%)" dominated the training.

5. The ability of participants to write a list of references in articles has increased. Before the training, the participants with the skill "quite mastered (53\%)", while after the training, the dominant participants were the participants with the skill "master (68\%)."

6. The ability of participants to present tables and figures according to the provisions of the journal has increased. Before the training, participants with the skill "quite mastered (53\%)", while after the training, participants with the skill "master (47\%)" dominated the training.

7. The ability of participants to search for journals for publication purposes has increased. Before the training, participants with the skill "quite mastered (42\%)", while after the training, participants with the skill "mastered (58\%)" dominated the training.

8. The ability of participants to submit articles to journals has increased. Before the training, participants with the skill "quite mastered (47\%)", while after the training, participants with the skill "mastered (58\%)" dominated the training.

9. The ability of participants to follow the flow of article publishing through OJS has increased. Before the training, participants with the skill "quite mastered (32\%)", while after the training, the participants with the skill "master (47\%)" dominated the training. 
Of all the skills that were evaluated to 19 participants (out of a total of 22 participants), the most dominant skills felt to be "mastered" were the skills to describe problems clearly in articles, write reference lists, present novelties, and apply theory specifically.

Surveys were conducted on participants and reviewers or assistants to the manuscript both before and after the training.

\begin{tabular}{|c|c|c|c|c|c|c|c|c|}
\hline \multirow{3}{*}{ Reviewer } & \multicolumn{9}{c|}{ Evaluation (average value) } \\
\cline { 2 - 11 } & \multicolumn{2}{|c|}{ Topic } & \multicolumn{2}{c|}{$\begin{array}{c}\text { Technical } \\
\text { Writing }\end{array}$} & \multicolumn{2}{c|}{$\begin{array}{c}\text { Opportunity } \\
\text { to Publish in } \\
\text { Journal }\end{array}$} & \multicolumn{2}{c|}{ Reference } \\
\cline { 2 - 11 } & $\mathrm{X}$ & $\mathrm{Y}$ & $\mathrm{X}$ & $\mathrm{Y}$ & $\mathrm{X}$ & $\mathrm{Y}$ & $\mathrm{X}$ & $\mathrm{Y}$ \\
\hline Reviewer 1 & 7.40 & 7.97 & 7.20 & 7.94 & 7.00 & 7.88 & 7.00 & 7.98 \\
\hline Reviewer 2 & 7.29 & 7.86 & 7.43 & 7.75 & 7.14 & 7.25 & 6.86 & 7.50 \\
\hline Reviewer 3 & 5.50 & 7.00 & 5.17 & 6.67 & 5.83 & 6.33 & 5.67 & 7.00 \\
\hline
\end{tabular}

Figure 7. Review of manuscripts by reviewers before and after training

\section{Information :}

$\mathrm{X}$ : Pre-training script assessment

Y: Script evaluation after training

The survey results show a significant increase from the four criteria of the manuscript being assessed. A reasonably high increase in the criteria for selecting the topics raised and technical writing.

\section{CONCLUSION AND FURTHER RESEARCH}

This study aims to find out how the Addie model used by the Department of Communication Sciences improves the pedagogic competence of lecturers in terms of the ability to write accredited journals. Based on the research findings obtained after the Analysis, Design, Development, Implementation, and Evaluation process, it can be concluded that; The training model developed is quite effective in increasing the ability of participants to write and produce scientific papers of international standard. This can be seen from the changes in the content of the manuscripts submitted before and after the training and the assessment carried out by the supervisor, which showed significant progress in the quality of the participants' writing.

Guided activities in compiling scientific papers following a writing format that followed the surrounding style of the journal of interest; followed by the opportunity to present the progress of writing and peer review sessions were able to improve the understanding of lecturers of the Department of Communication Sciences UPN Veteran Yogyakarta in compiling scientific papers in accordance with international standards.

The training activities also increased the perception of lecturers in the Department of Communication Sciences UPN Veteran Yogyakarta regarding their ability to write scientific papers for international publications.

The hope of lecturers in the Department of Communication Science who participate in this activity until the end is to be able to publish their writings in the target journal and hope that there will be a similar 
program that is sustainable and routine. So that in the future, activities can spur productivity and enthusiasm for writing for lecturers as one of the obligations of the tri dharma of higher education.

\section{REFERENCES}

Aldoobie, N. (2015) 'ADDIE Model', American International Journal of Contemporary Research, 5(6).

Allen, W. C. (2006) 'Overview and Evolution of the ADDIE Training System', Advances in Developing Human Resources, 8(4), pp. 430-441. doi: 10.1177/1523422306292942.

Azimi, K. and Rastegarpour, A. J. (2015) 'A Survey of the Effectiveness of Instructional Design ADDIE and Multimedia on Learning Key Skills of Futsal', Journal of Educational and Management Studies, 5(3), pp. 180-186. Available at: https://www.researchgate.net/profile/Jafar_Ahmadigol2/publication/291521394_A_Survey_of_t he_Effectiveness_of_Instructional_Design_ADDIE_and_Multimedia_on_Learning_Key_Skills_of_Futs al/links/56a3a42a08ae1b6511306bfb.pdf\%0Awww.science-line.com.

Borg, W. R. and Gall, M. D. . (1989) Educational research: An introduction. 5th edn. New York: Longman.

FAO (2021) E-learning methodologies and good practices: A guide for designing and delivering e-learning solutions from the FAO elearning Academy, E-learning methodologies and good practices. Available at: https://doi.org/10.4060/i2516e\%0Ahttp://www.fao.org/3/i2516e/i2516e.pdf.

Hovland, C. I. (2005) Ilmu Komunikasi Suatu Pengantar,terjemahan Dedy Mulyana. Jakarta: Erlangga.

Moradmand, N., Datta, A. and Oakley, G. (2014) 'The Design and Implementation of an Educational Multimedia Mathematics Software: Using ADDIE to Guide Instructional System Design', in.

Putra, N. (2015) Research and Development. Jakarta: PT. Grafindo Persada.

Sugiyono (2016) Metode Penelitian Kuantitatid, Kualitatif, R\&D. Bandung: Alfabeta.

Taylor, L. (2004) 'Educational Theories and Instructional Design Models . Their Place in Simulation .', Health. Available at: https://www.researchgate.net/publication/229039487_Educational_Theories_and_Instructional_ Design_Models_Their_Place_in_Simulation.

Vejvodová, J. (2009) 'The ADDIE Model: Dead or Alive?', in 10th International Conference Virtual University. Available at: http://virtuni.eas.sk/rocnik/2009/pdf/paper_127.pdf. 